\title{
BMJ Open Prevalence of general and abdominal obesity in 2015-2016 and 8-year longitudinal weight and waist circumference changes in adults and elderly: the Tromsø Study
}

Ola Løvsletten (1D , ${ }^{1}$ Bjarne K Jacobsen, ${ }^{1,2}$ Sameline Grimsgaard, ${ }^{1}$ Inger Njølstad, ${ }^{1}$ Tom Wilsgaard (D) , ${ }^{1}$ Maja-Lisa Løchen, ${ }^{1}$ Anne Elise Eggen, Laila Arnesdatter Hopstock ${ }^{1}$

To cite: Løvsletten 0 , Jacobsen BK, Grimsgaard S, et al. Prevalence of general and abdominal obesity in 20152016 and 8-year longitudinal weight and waist circumference changes in adults and elderly: the Troms $\emptyset$ Study. BMJ Open 2020;10:e038465. doi:10.1136/ bmjopen-2020-038465

- Prepublication history and additional material for this paper are available online. To view these files, please visit the journal online (http://dx.doi. org/10.1136/bmjopen-2020038465).

Received 12 March 2020 Revised 31 August 2020 Accepted 26 September 2020

Check for updates

(c) Author(s) (or their employer(s)) 2020. Re-use permitted under CC BY-NC. No commercial re-use. See rights and permissions. Published by BMJ.

${ }^{1}$ Department of Community Medicine, UiT The Arctic University of Norway, Tromsø, Norway

${ }^{2}$ Centre for Sami Health Research, Department of Community Medicine, UiT The Arctic University of Norway, Tromsø, Norway

Correspondence to Dr Ola Løvsletten; ola.lovsletten@uit.no

\section{ABSTRACT}

Objectives To describe the prevalence of general (body mass index $(\mathrm{BMI}) \geq 30 \mathrm{~kg} / \mathrm{m}^{2}$ ) and abdominal (waist circumference women $>88 \mathrm{~cm}$, men $>102 \mathrm{~cm}$ ) obesity in Troms $\emptyset 7$ (20152016), and the secular change from Troms 6 (2007-2008). Furthermore, to study longitudinal changes in body weight and waist circumference from Troms $\emptyset$ to Troms $\emptyset 7$.

Setting A population study in Troms $\emptyset$, Norway. Participants The cross-sectional analyses included 20855 participants in Troms $\emptyset$ (aged $\geq 40$ years) and 12868 in Troms $\emptyset 6$ (aged $\geq 30$ years). The longitudinal analyses included 8592 participants with repeated measurements, aged 35-79 in Troms $\emptyset 6$.

Outcome measures Mean age-specific and sex-specific $\mathrm{BMI}$, waist circumference, prevalence of general and abdominal overweight and obesity, as well as longitudinal changes in body weight and waist circumference according to sex and birth cohort.

Results Over 8 years, the age-adjusted prevalence of general obesity increased $(p<0.0001)$ from $20.1 \%$ to $23.0 \%$ in women and from $20.7 \%$ to $25.2 \%$ in men. The age-adjusted prevalence of abdominal obesity did not increase in women (from $54.7 \%$ to $53.4 \%$ ), and the increase in men was modest (from $36.8 \%$ to $38.6 \%$, $\mathrm{p}=0.003)$. Longitudinal analyses showed an increase in body weight, by $1.1 \mathrm{~kg}(95 \% \mathrm{Cl} 0.9$ to 1.2$)$ in women and $0.7 \mathrm{~kg}(95 \% \mathrm{Cl} 0.6$ to 0.9$)$ in men, and also waist circumference, by $1.3 \mathrm{~cm}(95 \% \mathrm{Cl} 1.0$ to 1.5$)$ in women and $1.4 \mathrm{~cm}(95 \% \mathrm{Cl} 1.2$ to 1.6$)$ in men. There were inverse relationships $(p<0.001)$ between age at baseline and change in weight and waist circumference.

Conclusions Repeated cross-sectional analyses showed that the prevalence of general obesity increased, whereas the increase in abdominal obesity was less marked. Longitudinal analyses showed increases in both body weight and waist circumference. The youngest age groups have the largest increase.

\section{INTRODUCTION}

There is an increasing prevalence of general obesity (body mass index (BMI) $\geq 30 \mathrm{~kg}$ / $\mathrm{m}^{2}$ ) in most parts of the world, also in

\section{Strengths and limitations of this study}

Waist, weight and height were measured, not self-reported.

- Population-based study with a relative large number of participants; 21083 in the seventh survey of the Tromsø Study (Tromsø 7) and 12984 in Troms $\emptyset$ 6. A subset of participants, $n=8906$, attended both surveys.

- High attendance; $66 \%$ in Troms $\emptyset 6 \%$ and $65 \%$ in Troms $\emptyset 7$.

- Among the elderly there may be a selection bias due to healthy individuals who participate in the study.

high-income countries, ${ }^{12}$ and probably more in rural than in urban areas. ${ }^{3}$ General obesity is an important risk factor for several noncommunicable diseases ${ }^{1}$ (NCDs), and halting the rise in obesity is part of WHO's global action plan to prevent and reduce NCDs. ${ }^{4}$

Abdominal obesity (waist circumference $>88 \mathrm{~cm}$ in women and $>102 \mathrm{~cm}$ in men) is a significant predictor of obesity-related diseases ${ }^{56}$ and all-cause mortality. ${ }^{7-9}$ Information about the prevalence of abdominal obesity is therefore of major interest.

We have previously reported secular trends in mean BMI as well as the prevalence of general obesity in a large population in Norway from 1974 to $2008^{10} 11^{1}$ and corresponding figures for waist circumference and abdominal obesity from 1994 to $2008 .^{12}$ Furthermore, we have published longitudinal changes in the same obesity-related measures. ${ }^{10-12}$

The aim of this study was to describe the obesity epidemic in Norway with crosssectional data from the last survey of the Troms $\varnothing$ Study in 2015-2016 (Tromsø 7), and 
to study the longitudinal changes in body weight and waist circumference from the sixth survey of Troms $\varnothing$ Study in 2007-2008 (Tromsø 6).

\section{MATERIAL AND METHODS \\ The Tromsø study}

The Troms $\varnothing$ Study is an ongoing population-based cohort study, based in Tromsø. ${ }^{13} 14$ The study includes seven surveys (Tromsø 1-Tromsø 7) between 1974 and 20152016, to which total birth cohorts and representative samples from Troms $\varnothing$ municipality are invited. Troms $\varnothing$ is the largest populated municipality in Northern Norway with $\sim 65000$ inhabitants in 2008 and 73000 inhabitants in 2016, including both urban and rural living areas. The present analyses are based on data from the sixth (Troms $\varnothing 6$ ) and seventh survey (Tromsø 7), conducted in 2007-2008 and 2015-2016, respectively.

In Tromsø 6, four different groups were invited; participants who took part in a comprehensive examination in Tromsø 4 (conducted in 1994-1995), a 10\% random sample of the age group 30-39, everyone in the age groups $40-42$ and $60-87$, and a $40 \%$ random sample of people aged $43-49$ years $(\mathrm{n}=19762)$, and 12984 men and women aged 30-87 years attended (66\%). In Troms $\varnothing 7$, all inhabitants of Troms $\varnothing$ municipality aged 40 and older were invited ( $\mathrm{n}=32591)$, and 21083 men and women aged 40-99 years attended (65\%). A total of 8906 attended both Tromsø 6 and Tromsø 7.

The participants gave written informed consent.

\section{Public involvement}

The Norwegian Health Association (https://nasjonalforeningen.no/) was member of the steering group for
Tromsø 7. There is an ongoing research communication between the Troms $\varnothing$ Study and the community.

\section{Measurements}

Body height and weight were measured to the nearest $0.1 \mathrm{~cm}$ and $100 \mathrm{~g}$, respectively. Waist circumference was measured at the umbilical level by a tape measure, to the nearest centimetre. All measurements were performed by trained staff with the participant standing and breathing normally, with light clothing and no footwear.

BMI was calculated as weight divided by the square of height $\left(\mathrm{kg} / \mathrm{m}^{2}\right)$ categorised into underweight $(<18.5 \mathrm{~kg} /$ $\left.\mathrm{m}^{2}\right)$, normal $\left(18.5-24.9 \mathrm{~kg} / \mathrm{m}^{2}\right)$, overweight $(25-29.9 \mathrm{~kg} /$ $\left.\mathrm{m}^{2}\right)$, obese class $1\left(30.0-34.9 \mathrm{~kg} / \mathrm{m}^{2}\right)$, class $2(35.0-$ $\left.39.9 \mathrm{~kg} / \mathrm{m}^{2}\right)$ or class $3\left(\geq 40.0 \mathrm{~kg} / \mathrm{m}^{2}\right){ }^{15}$

The age group 75-79 (age in 2007) experienced a height reduction of $1.4 \mathrm{~cm}$ in women and $1.2 \mathrm{~cm}$ in men, from Troms $\varnothing 6$ to Troms $\varnothing 7$. Height loss increases BMI and also waist/height ratio (under the assumption of no change in weight and waist circumference).

For instance, a height reduction of $3 \mathrm{~cm}$, from 1.80 to $1.77 \mathrm{~cm}$ in a person with body weight $70 \mathrm{~kg}$, gives a $0.7 \mathrm{~kg} /$ $\mathrm{m}^{2}$ higher BMI. Therefore, weight and waist circumference are the dependent variables in the longitudinal analyses. Thus, we avoid a potential masking of weight loss in the elderly, which can be a problem for BMI. ${ }^{16}$

\section{Sample}

After exclusions, the cross-sectional analyses of BMI in Tromsø 7 include data from 20855 participants (10932 women and 9923 men), whereas for waist circumference the sample size was 20953 participants (10991 women and 9962 men). Pregnant women and participants with other remarks concerning the waist, height or weight

Table 1 Mean body mass index (BMI, $\left.\mathrm{kg} / \mathrm{m}^{2}\right)$, and prevalence of overweight and obesity by gender and age groups in Troms $\varnothing$ $7(2015-2016)^{\star}$

\begin{tabular}{|c|c|c|c|c|c|c|c|c|}
\hline \multirow[b]{2}{*}{ Age } & \multicolumn{4}{|c|}{ Women $(n=10932)$} & \multicolumn{4}{|c|}{ Men $(n=9923)$} \\
\hline & $\mathbf{n}$ & $\begin{array}{l}\text { Mean (SD) } \\
\text { BMI }\end{array}$ & $\begin{array}{l}\text { \% overweight } \\
\text { (95\% Cl†) }\end{array}$ & $\begin{array}{l}\% \text { obese } \\
\text { (95\% Cl†) }\end{array}$ & $\mathbf{n}$ & $\begin{array}{l}\text { Mean } \\
\text { (SD) BMI }\end{array}$ & $\begin{array}{l}\% \text { overweight }(95 \% \\
\mathrm{Cl}+)\end{array}$ & $\begin{array}{l}\% \text { obese } \\
\text { (95\% Cl†) }\end{array}$ \\
\hline $45-49$ & 1686 & $27.0(5.3)$ & 31.9 (29.6 to 34.1$)$ & 24.8 (22.7 to 26.9 ) & 1574 & $28.1(4.2)$ & 50.1 (47.6 to 52.6 ) & 27.3 (25.1 to 29.6 ) \\
\hline $50-54$ & 1690 & $26.6(4.9)$ & 34.7 (32.4 to 37.0$)$ & 20.9 (19.0 to 22.9 ) & 1429 & $27.9(4.1)$ & 50.9 (48.3 to 53.6$)$ & 25.5 (23.3 to 27.9$)$ \\
\hline $65-69$ & 1245 & $27.0(4.7)$ & 40.5 (37.7 to 43.3$)$ & 22.5 (20.2 to 24.9$)$ & 1165 & $27.8(3.8)$ & 52.6 (49.7 to 55.5$)$ & 24.1 (21.7 to 26.7$)$ \\
\hline $70-74$ & 840 & $27.8(5.0)$ & 40.2 (36.9 to 43.6$)$ & 28.6 (25.5 to 31.8 ) & 845 & $27.8(3.9)$ & 50.8 (47.3 to 54.2 ) & 25.2 (22.3 to 28.3 ) \\
\hline $75-79$ & 488 & $27.0(4.8)$ & 42.8 (38.4 to 47.4$)$ & 22.5 (18.9 to 26.5 ) & 453 & $27.4(3.8)$ & 50.8 (46.1 to 55.5$)$ & $21.0(17.3$ to 25.0$)$ \\
\hline $80-84$ & 257 & $26.7(4.4)$ & 45.1 (38.9 to 51.4$)$ & 20.6 (15.8 to 26.1$)$ & 237 & $26.9(3.5)$ & 47.3 (40.8 to 53.8 ) & 18.1 (13.5 to 23.7$)$ \\
\hline
\end{tabular}

The Tromsø study.

*Overweight, BMI 25-29.9; obesity, BMI $\geq 30$.

†Exact (Clopper-Pearson) $\mathrm{Cl}$ from the binomial distribution. 


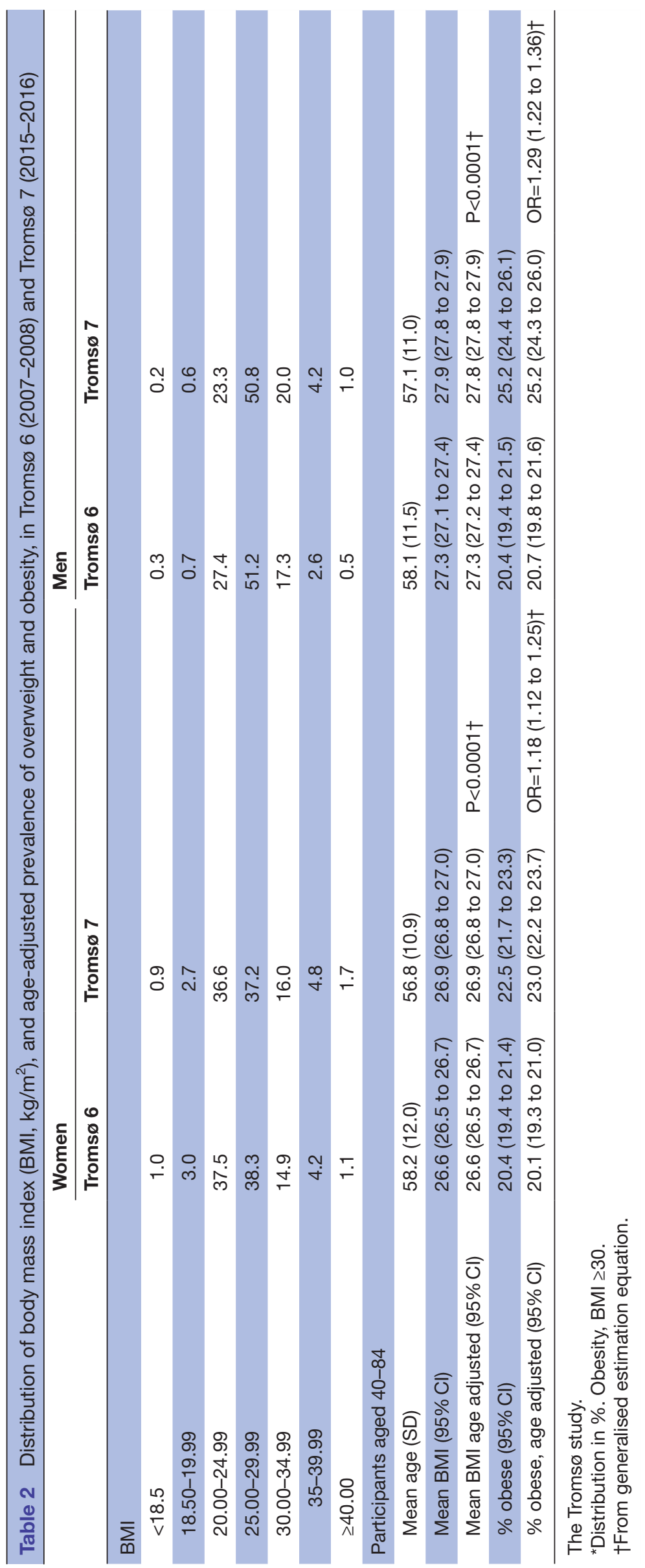


measurement (eg, scoliosis, measured with shoes) were excluded from the analyses $(\mathrm{n}=165$ for BMI and $\mathrm{n}=38$ for waist). In Troms $\varnothing$ 6, after exclusions, 12868 had a measurement of BMI and 12493 a measurement of waist. ${ }^{11} 12$

Altogether 4580 women and 4012 men were included in the longitudinal analysis of body weight. The corresponding analysis of waist circumference included 4506 women and 3916 men. We included subjects aged 35-79 in Troms $\varnothing 6$ (born 1928-1972) with valid measurements in both Tromsø 6 and Troms $\varnothing 7$. Participants aged $\geq 80$ years in 2007 were not included because only 78 individuals $(15 \%)$ of them also participated in Troms $\varnothing 7$.

A total of 5737 men and 6410 women aged 35-79 in Troms $\varnothing 6$ had a valid measurement of body weight, and $71 \%$ of them also had a valid measurement of weight in Troms $\varnothing 7$. The main reasons for not attending the survey in 2015-2016 included death or moving out of Troms $\varnothing$ (1261 subjects) or non-attendance without justification despite being invited (2107 subjects). Comparing mean body weight in Troms $\varnothing 6$ among men and women who attended both Troms $\varnothing 6$ and Troms $\varnothing 7$ (n=8592), to those who attended Troms $\varnothing 6$ only $(\mathrm{n}=3555)$, showed no significant difference (age-adjusted $0.63 \mathrm{~kg}$ higher $(\mathrm{p}=0.10)$ in men and $0.39 \mathrm{~kg}$ lower $(\mathrm{p}=0.29)$ in women in subjects who attended both surveys). Similar results were found for difference in waist circumference, though women who attended Troms $\varnothing 6$ only had a $0.7 \mathrm{~cm}(\mathrm{p}=0.04)$ higher waist circumference. In men, the difference was a nonsignificant $0.5 \mathrm{~cm}(\mathrm{p}=0.13)$.

\section{Statistical analyses}

We present results from cross-sectional analyses of data from Tromsø 7 according to age groups in Tromsø 7 , whereas the longitudinal analyses are presented according to age groups in Troms $\varnothing$ 6. Age is given in years, per 31.12.2007 in Troms $\varnothing 6$, and per 31.12.2015 in Troms $\varnothing 7$. We computed age-adjusted mean BMI and waist circumference, as well as the age-adjusted prevalence of general obesity and abdominal obesity, for participants aged 40-84. Herein, to take into account the dependence caused by some participants attending both surveys we applied generalised estimation equations (GEE) with a non-zero correlation, and age adjusted by setting the covariate age equal to the mean value ( 57.4 years).

In the longitudinal analysis, we examined whether the change in waist circumference was larger than expected based on the difference in body weight and age from Troms $\varnothing 6$ to Troms $\varnothing 7$, as described previously. ${ }^{12}$ We assumed that weight and age together predicted waist circumference in the same way in Troms $\varnothing 6$ as in Troms $\varnothing 7$. Based on the linear relationship in Troms $\varnothing 6$, we predicted the waist circumference in Troms $\varnothing 7$. The expected waist circumference was compared with that observed in Tromsø 7.

All analyses were conducted using SAS V.9.4. ${ }^{17}$ The figures were made in $\mathrm{R}^{18}$ using the R-package ggplot2. ${ }^{19}$ The statistical analyses included descriptive statistics,
GEE, paired t-tests and linear regression. Assumptions in the statistical models were assessed graphically by residual analyses. A $p<0.05$ was considered statistically significant.

\section{RESULTS}

\section{Cross-sectional analyses}

Table 1 and (online supplemental figure S1) gives the cross-sectional findings regarding BMI in Troms $\varnothing$ 7. A larger proportion of men than women were classified as being overweight.

The prevalence of underweight was low $(\leq 1 \%)$ in both women and men in both surveys. Age-adjusted mean BMI increased in both genders from Troms $\varnothing 6$ to Troms $\varnothing 7$ $(\mathrm{p}<0.0001)$. The age-adjusted OR for being obese in Troms $\varnothing 7$, relative to Troms $\varnothing 6$, was 1.18 (95\% CI 1.12 to 1.25 ) in women and 1.29 (95\% CI 1.22 to 1.36 ) in men (table 2). Cross-sectional results for waist circumference in Troms $\varnothing 7$ are given in table 3 and online supplemental figure S2. The mean waist circumference was higher than the overweight lower limit in men, and higher than the obese lower limit in women.

Table 4 displays the crude and age-adjusted mean waist circumference and prevalence of abdominal obesity in participants aged 40-84 in Tromsø 7, and results for Troms $\varnothing 6$ for comparison. The change in age-adjusted mean waist circumference was not statistically significant in women $(0.1 \mathrm{~cm}, \mathrm{p}=0.41)$, whereas men had a $0.7 \mathrm{~cm}$ increase $(\mathrm{p}<0.0001)$. The age-adjusted OR for being abdominal obese in Tromsø 7, relative to Tromsø 6, was 0.95 (95\% CI 0.91 to 1.00$)$ in women and 1.08 (95\% CI 1.03 to 1.14 ) in men.

\section{Longitudinal analyses}

Table 5 displays the longitudinal changes in body weight between Troms $\varnothing 6$ and Troms $\varnothing 7$. Mean weight increased by $1.1 \mathrm{~kg}$ and $0.7 \mathrm{~kg}$, in women and men, respectively. An inverse, approximately linear, relationship was found between age in Troms $\varnothing 6$ and the change in weight over the next 8 years (online supplemental figure S3). We observed a statistically significant increase in body weight in men and women aged 35-59 years, while there was a statistically significant decrease in weight in participants aged $65-79$ years.

Change in waist circumference from Troms $\varnothing 6$ to Troms $\varnothing 7$ is displayed in table 6 (and online supplemental figure $\mathrm{S} 4$ ). We observed statistically significant increases in waist circumference in both men and women. An inverse relationship was found between age at baseline and the change in waist circumference the next 8 years. We observed a statistically significant increase in waist circumference in subjects aged $<70$ years, whereas there was no significant changes in subjects in their 70 s.

Comparing the estimated waist circumference in Troms $\varnothing 7$ with that expected based on the relationship between waist circumference, weight and age in Troms $\varnothing$ 6 , revealed a larger-than-expected increase in waist 


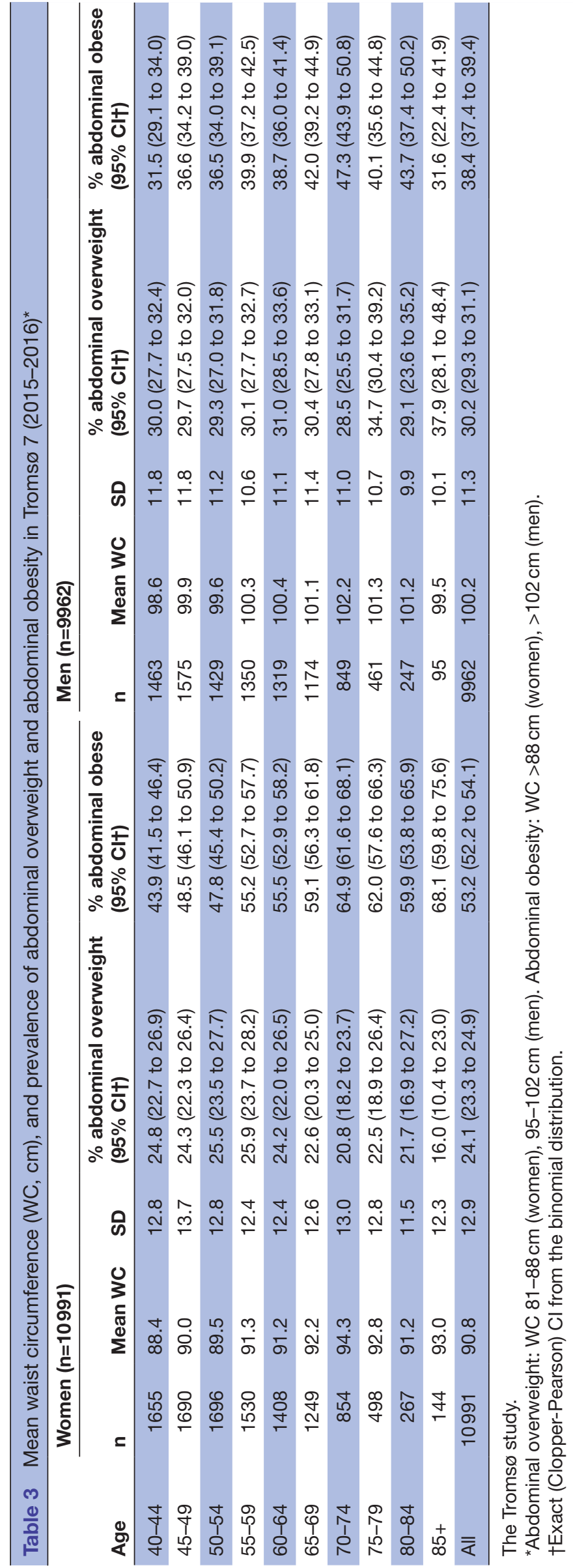




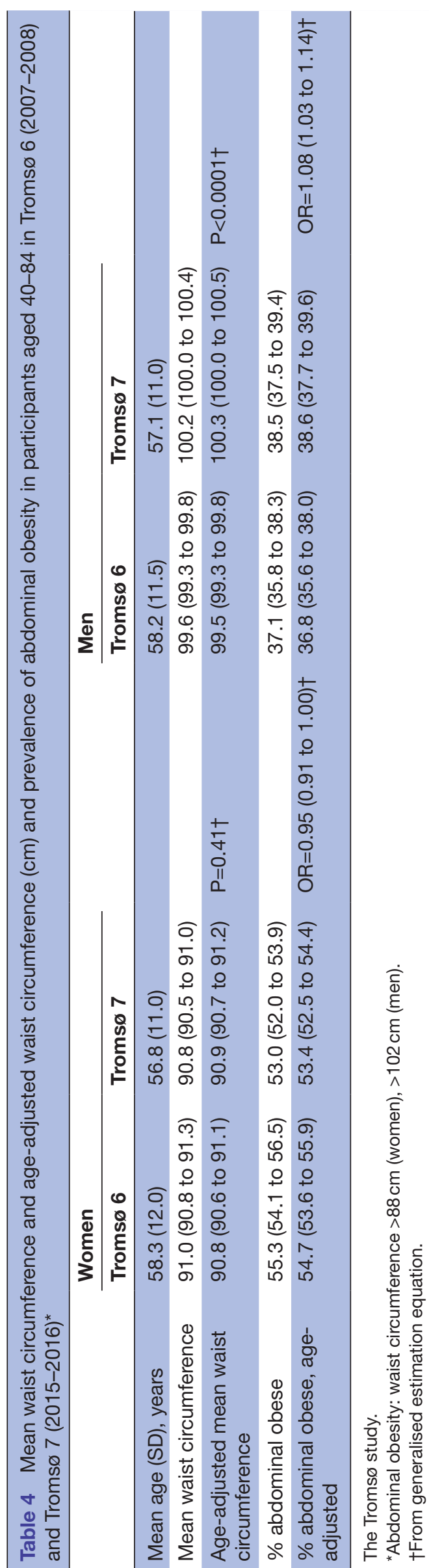

circumference in both women, $0.7 \mathrm{~cm}$ (95\% CI 0.6 to $0.9)$, and men, $0.8 \mathrm{~cm} \mathrm{(95 \%} \mathrm{CI} 0.6$ to 0.9$)$.

\section{DISCUSSION}

Repeated cross-sectional analyses of BMI in a large population in Norway showed an increase in mean BMI and prevalence of obesity from 2007 to 2008 to 2015-2016. Secular changes in waist circumference and abdominal obesity were less marked. Longitudinal results among a subset of participants showed an overall increase in both weight and waist circumference from 2007-2008 to 2015-2016. However, age-related differences were observed; weight and waist circumference increased most in the youngest, whereas the oldest participants had no significant change in waist circumference and lost weight.

The prevalence of general obesity was $25 \%$ for men and $23 \%$ for women in Troms $\varnothing 7$, higher than any of the six previous surveys of the Troms $\varnothing$ Study. ${ }^{1011}$ Moreover, $6.5 \%$ of the women and $6.2 \%$ of the men have BMI $\geq 35 \mathrm{~kg} / \mathrm{m}^{2}$. An increase in obesity has also been found in the National Health and Nutrition Examination Survey, for the same time period, 2007-2008 to 2015-2016. ${ }^{20}$ A population-based study in mid-Sweden, where height and weight were self-reported, also showed an increase in obesity between 2000 and 2012, although at a lower rate from $2008 .{ }^{21}$

Previous analyses from the Troms $\varnothing$ Study have shown that the prevalence of abdominal obesity nearly doubled between 1994 and 2007. ${ }^{12}$ In women, we found no change in age-adjusted mean waist circumference from Tromsø 6 to Troms $\varnothing 7$, in contrast to the increase in BMI. This result could reflect a small secular change in body composition, but we cannot exclude a measurement error in waist circumference since it is difficult to measure accurately. ${ }^{922}$ While cross-sectional comparisons showed no change in waist circumference in women, there was a significant increase longitudinally. In the cross-sectional analyses, we found that the age-specific mean waist circumference figures were similar in Troms $\varnothing 6$ and Troms $\varnothing 7$, and that there were a modest increase in waist circumference with advancing age (table 3 ) at least to the age of 70 . Therefore, the age-adjusted figures in Troms $\varnothing 6$ and Troms $\varnothing 7$ were similar (table 4). However, in the longitudinal analyses, we assessed the 8-year change in waist circumference in the subjects that attended both surveys. In subjects aged less than 70, we found an increase in waist circumference (table 6), in concordance with the cross-sectional findings of a modest increase in waist circumference with advancing age.

There is a large difference in the prevalence of general and abdominal obesity. For women, where the difference is most pronounced, $53 \%$ are classified as abdominal obese whereas $23 \%$ have BMI $\geq 30 \mathrm{~kg} / \mathrm{m}^{2}$. Similar discrepancies have also been found earlier, and it has been suggested that these two measures of obesity need to be harmonised. ${ }^{12}$ However, as pointed out by Midthjell $e t a l,{ }^{23} \mathrm{BMI}$ 
Table 5 Mean body weight (kg) in Tromsø 6 (2007-2008), Tromsø 7 (2015-2016) and change in weight

\begin{tabular}{|c|c|c|c|c|c|c|c|}
\hline \multirow[b]{2}{*}{ Age 2007 , years } & \multirow[b]{2}{*}{$\mathbf{N}$} & \multicolumn{2}{|l|}{ Tromsø 6} & \multicolumn{2}{|l|}{ Tromsø 7} & \multicolumn{2}{|c|}{$\begin{array}{l}\text { Change between Troms } \varnothing 6 \text { and } \\
\text { Troms } \varnothing 7\end{array}$} \\
\hline & & Mean weight & SD & Mean weight & SD & Mean weight & $95 \% \mathrm{Cl}^{*}$ \\
\hline \multicolumn{8}{|l|}{ Women } \\
\hline $35-39$ & 123 & 70.8 & 12.5 & 73.9 & 12.9 & 3.1 & 1.9 to 4.4 \\
\hline $40-44$ & 955 & 70.6 & 13.2 & 73.6 & 14.2 & 3.0 & 2.6 to 3.4 \\
\hline $45-49$ & 502 & 71.8 & 13.6 & 74.0 & 14.3 & 2.2 & 1.7 to 2.8 \\
\hline $50-54$ & 533 & 69.5 & 11.4 & 71.2 & 12.3 & 1.7 & 1.3 to 2.1 \\
\hline $55-59$ & 486 & 70.9 & 12.8 & 71.6 & 13.3 & 0.7 & 0.3 to 1.2 \\
\hline $60-64$ & 953 & 72.4 & 12.4 & 72.7 & 13.0 & 0.3 & -0.0 to 0.6 \\
\hline $65-69$ & 562 & 71.0 & 13.1 & 70.3 & 13.0 & -0.6 & -1.1 to 0.2 \\
\hline $70-74$ & 301 & 69.8 & 12.0 & 68.7 & 12.4 & -1.1 & -1.7 to 0.5 \\
\hline $75-79$ & 165 & 69.7 & 12.3 & 67.9 & 12.9 & -1.8 & -2.6 to 1.0 \\
\hline All women & 4580 & 71.0 & 12.7 & 72.1 & 13.4 & 1.1 & 0.9 to 1.2 \\
\hline \multicolumn{8}{|l|}{ Men } \\
\hline $35-39$ & 92 & 90.4 & 13.3 & 93.2 & 15.5 & 2.9 & 1.6 to 4.1 \\
\hline $40-44$ & 774 & 87.4 & 13.5 & 89.7 & 14.6 & 2.3 & 1.8 to 2.7 \\
\hline $45-49$ & 452 & 86.9 & 12.8 & 88.9 & 13.8 & 2.0 & 1.5 to 2.5 \\
\hline $50-54$ & 412 & 86.8 & 12.1 & 87.7 & 13.1 & 0.9 & 0.4 to 1.4 \\
\hline $55-59$ & 467 & 86.2 & 13.1 & 86.8 & 13.1 & 0.5 & 0.0 to 1.0 \\
\hline $60-64$ & 848 & 86.4 & 12.6 & 86.6 & 12.8 & 0.1 & -0.2 to 0.5 \\
\hline $65-69$ & 571 & 84.5 & 12.1 & 84.1 & 13.0 & -0.4 & -0.9 to 0.0 \\
\hline $70-74$ & 291 & 81.6 & 11.5 & 80.5 & 11.8 & -1.1 & -1.7 to 0.6 \\
\hline $75-79$ & 105 & 79.8 & 10.3 & 78.5 & 12.2 & -1.3 & -2.4 to 0.2 \\
\hline All men & 4012 & 86.0 & 12.8 & 86.7 & 13.7 & 0.7 & 0.6 to 0.9 \\
\hline
\end{tabular}

The Tromsø study.

${ }^{*} \mathrm{Cl}$ based on the paired t-statistic.

and waist circumference are different measures. Gaining muscle mass will increase BMI, and thus waist circumference may be a better measure of body fat. On the other hand, weight and height are less prone to measurement error.

Weight and waist circumference increased most in the youngest, which seems to be a consistent finding from many studies. ${ }^{10-1224-32}$ The waist circumference increased relatively more than weight, confirming previous findings in the Tromsø Study and other cohorts. ${ }^{123-37}$

It has been found that the probability of an obese person attaining normal weight is low, and also that maintaining weight loss is difficult. ${ }^{38}$ Thus, prevention of obesity is important, in particular for the youngest who have the largest weight gain. There is also a need for public health interventions to help obese people attaining normal- or overweight. Target 7 in WHO's action plan is a halt in prevalence of obesity and diabetes by 2025 against a baseline in $2010 .{ }^{4}$ The results presented in this paper show that Norway is not on track to reach this goal in 2015-2016.
Change in food supply has been found to be sufficient to explain the mean body weight gain. ${ }^{39}$ Thus, the most likely cause for the increase in obesity is higher intake of energy. In the Troms $\varnothing$ Study, studying change in food habits are currently not possible as an extensive food frequency questionnaire was used for the first time in Troms $\varnothing 7 .^{40}$ However, this study population have self-reported physical activity in all surveys and there has been an increase in sedentary occupational activity though it may be counteracted by increased physical activity during leisure time. ${ }^{41}$ Thus, it is currently unclear whether this change in physical activity in the Tromsø population can explain part of the increase in the prevalence of obesity.

With the exception of some of the cross-sectional results from Troms $\varnothing 6,{ }^{11}{ }^{12}$ which we included in this paper for comparison, and some selected results published on the web site of the Norwegian Institute of Public Health as part of the Norwegian NCD collaboration, ${ }^{42}$ the results in this paper have not been published before. 
Table 6 Mean waist circumference in Tromsø 6 (2007-2008), Tromsø 7 (2015-2016) and change in waist circumference

\begin{tabular}{|c|c|c|c|c|c|c|c|}
\hline \multirow[b]{2}{*}{ Age 2007 , years } & \multirow[b]{2}{*}{$\mathbf{N}$} & \multicolumn{2}{|c|}{ Tromsø 6 (2007-2008) } & \multicolumn{2}{|c|}{ Tromsø 7 (2015-2016) } & \multicolumn{2}{|c|}{$\begin{array}{l}\text { Change between Troms } \varnothing 6 \\
\text { and Troms } \varnothing 7\end{array}$} \\
\hline & & Mean, cm & SD & Mean, cm & SD & Mean, cm & $95 \% \mathrm{Cl}^{*}$ \\
\hline \multicolumn{8}{|l|}{ Women } \\
\hline $35-39$ & 118 & 89.3 & 12.8 & 89.8 & 13.1 & 0.5 & -1.2 to 2.1 \\
\hline $40-44$ & 917 & 88.1 & 11.7 & 89.9 & 12.9 & 1.8 & 1.3 to 2.4 \\
\hline $45-49$ & 484 & 90.2 & 12.8 & 91.9 & 13.2 & 1.8 & 1.0 to 2.5 \\
\hline $50-54$ & 523 & 88.4 & 10.6 & 90.0 & 11.3 & 1.6 & 0.9 to 2.2 \\
\hline $55-59$ & 482 & 90.5 & 12.1 & 91.6 & 12.7 & 1.1 & 0.4 to 1.7 \\
\hline $60-64$ & 943 & 92.8 & 11.8 & 94.0 & 12.7 & 1.1 & 0.7 to 1.6 \\
\hline $65-69$ & 568 & 92.0 & 11.3 & 93.0 & 12.0 & 1.0 & 0.4 to 1.6 \\
\hline $70-74$ & 302 & 91.8 & 12.1 & 92.1 & 12.3 & 0.4 & -0.5 to 1.3 \\
\hline $75-79$ & 169 & 92.8 & 11.3 & 92.6 & 12.4 & -0.2 & -1.4 to 1.0 \\
\hline All women & 4506 & 90.5 & 11.9 & 91.8 & 12.6 & 1.3 & 1.0 to 1.5 \\
\hline \multicolumn{8}{|l|}{ Men } \\
\hline $35-39$ & 86 & 98.8 & 10.1 & 100.7 & 12.5 & 1.8 & 0.5 to 3.2 \\
\hline $40-44$ & 738 & 97.5 & 10.4 & 99.3 & 11.8 & 1.8 & 1.2 to 2.3 \\
\hline $45-49$ & 417 & 97.2 & 10.0 & 99.8 & 10.9 & 2.6 & 1.9 to 3.2 \\
\hline $50-54$ & 404 & 98.6 & 10.2 & 100.0 & 11.1 & 1.4 & 0.8 to 2.1 \\
\hline $55-59$ & 460 & 99.4 & 10.4 & 100.9 & 11.2 & 1.5 & 0.9 to 2.1 \\
\hline $60-64$ & 836 & 100.8 & 10.2 & 102.1 & 10.6 & 1.3 & 0.8 to 1.7 \\
\hline $65-69$ & 571 & 100.8 & 9.8 & 101.6 & 11.0 & 0.9 & 0.3 to 1.4 \\
\hline $70-74$ & 295 & 100.0 & 9.9 & 100.5 & 9.9 & 0.5 & -0.2 to 1.2 \\
\hline $75-79$ & 109 & 99.9 & 9.9 & 100.6 & 10.1 & 0.7 & -0.6 to 1.9 \\
\hline All men & 3916 & 99.3 & 10.2 & 100.7 & 11.1 & 1.4 & 1.2 to 1.6 \\
\hline
\end{tabular}

The Tromsø study

${ }^{*} \mathrm{Cl}$ based on the paired t-statistic.

\section{Strengths and limitations}

Waist circumference, weight and height were measured by trained personnel using standardised procedures. Compared with self-reported height and weight, which tend to be biased, ${ }^{43}$ this is a significant strength. Another strength is that the data are from a population-based study with a high attendance, $66 \%$ in Tromsø $6 \%$ and $65 \%$ in Troms $\varnothing 7$. Still, a significant proportion of those invited did not participate. The attendance is lower among men than women, and the youngest and oldest have a lower attendance (www.tromsostudy.com).

A comparison between participants who attended both Troms $\varnothing 6$ and Troms $\varnothing 7$, and those who attended Troms $\varnothing 6$ only, showed small, and mostly non-significant, differences in mean weight, and also mean waist circumference. This is an indication that there is no substantial attrition bias in the longitudinal analysis. Among the elderly, there may be a bias caused by death or severe illness. For instance, in the oldest age group, that is, those aged 75-79 years in 2007, the attendance in Troms $\varnothing 7$ were $38 \%$ in women and $33 \%$ in men. For all other age groups the attendance was above $50 \%$.

\section{CONCLUSION}

We found a high proportion of general and abdominal obesity in both men and women, and a continuation of the increase in obesity during a follow-up of 8 years.

Longitudinal analyses with 8-year follow-up of participants aged 35-79 in 2007 showed statistically significant increases in both body weight and waist circumference in participants below the age of approximately 60 years for weight and 70 years for waist circumference. The youngest age groups have the largest increase.

Acknowledgements We thank all participants that attended the Tromsø Study. The publication charges for this article have been funded by the publication fund of UiT The Arctic University of Norway.

Contributors $\mathrm{OL}$ and BKJ wrote the first draft. OL performed the analysis. OL, BKJ, SG, IN, TW, M-LL, AEE and LAH interpreted the results, critically revised the manuscript, gave final approval and agreed to be accountable for all aspects of the work.

Funding The authors have not declared a specific grant for this research from any funding agency in the public, commercial or not-for-profit sectors.

Competing interests None declared.

Patient consent for publication Not required. 
Ethics approval The Regional Committee of Medical and Health Research Ethics (REK Nord 2014/940) and the Norwegian Data Protection Authority approved of the Tromsø Study.

Provenance and peer review Not commissioned; externally peer reviewed.

Data availability statement Data may be obtained from a third party and are not publicly available. The data are available on application for data access to the Tromsø Study. More information can be found on www.tromsostudy.com.

This content has been supplied by the author(s). It has not been vetted by BMJ Publishing Group Limited (BMJ) and may not have been peer-reviewed. Any opinions or recommendations discussed are solely those of the author(s) and are not endorsed by BMJ. BMJ disclaims all liability and responsibility arising from any reliance placed on the content. Where the content includes any translated material, BMJ does not warrant the accuracy and reliability of the translations (including but not limited to local regulations, clinical guidelines, terminology, drug names and drug dosages), and is not responsible for any error and/or omissions arising from translation and adaptation or otherwise.

Open access This is an open access article distributed in accordance with the Creative Commons Attribution Non Commercial (CC BY-NC 4.0) license, which permits others to distribute, remix, adapt, build upon this work non-commercially, and license their derivative works on different terms, provided the original work is properly cited, appropriate credit is given, any changes made indicated, and the use is non-commercial. See: http://creativecommons.org/licenses/by-nc/4.0/.

\section{ORCID iDs}

Ola Løvsletten http://orcid.org/0000-0001-9483-9621

Tom Wilsgaard http://orcid.org/0000-0002-2709-9472

\section{REFERENCES}

1 NCD Risk Factor Collaboration (NCD-RisC). Trends in adult bodymass index in 200 countries from 1975 to 2014: a pooled analysis of 1698 population-based measurement studies with $19 \cdot 2$ million participants. Lancet 2016;387:1377-96.

2 Abarca-Gómez L, Abdeen ZA, Hamid ZA, et al. Worldwide trends in body-mass index, underweight, overweight, and obesity from 1975 to 2016: a pooled analysis of 2416 population-based measurement studies in 128.9 million children, adolescents, and adults. The Lancet 2017;390:2627-42.

3 Popkin BM. Rural areas drive increases in global obesity. Nature 2019;569:200-1.

4 World Health Organization. About 9 voluntary global targets. Available: https://www.who.int/nmh/ncd-tools/definition-targets/en/ [Accessed 11 Mar 2020].

5 Janssen I, Katzmarzyk PT, Ross R. Waist circumference and not body mass index explains obesity-related health risk. Am J Clin Nutr 2004;79:379-84.

6 Janssen I, Mark AE. Separate and combined influence of body mass index and waist circumference on arthritis and knee osteoarthritis. Int $J$ Obes 2006;30:1223-8.

7 Seidell JC. Waist circumference and waist/hip ratio in relation to all-cause mortality, cancer and sleep apnea. Eur J Clin Nutr 2010;64:35-41.

8 Bigaard J, Frederiksen K, Tjønneland A, et al. Waist circumference and body composition in relation to all-cause mortality in middleaged men and women. Int J Obes 2005;29:778-84.

9 World Health Organization. Waist circumference and waist-hip ratio. Report of a who expert consultation. Geneva: World Health Organization, 2008.

10 Jacobsen BK, Njølstad I, Thune I, et al. Increase in weight in all birth cohorts in a general population: the Tromsø study, 1974-1994. Arch Intern Med 2001;161:466-72.

11 Jacobsen BK, Aars NA. Changes in body mass index and the prevalence of obesity during 1994-2008: repeated cross-sectional surveys and longitudinal analyses. The Tromso study. BMJ Open 2015;5:e007859.

12 Jacobsen BK, Aars NA. Changes in waist circumference and the prevalence of abdominal obesity during 1994-2008 - cross-sectional and longitudinal results from two surveys: the Troms $ø$ Study. BMC Obes 2016;3:41.

13 Eggen AE, Mathiesen EB, Wilsgaard T, et al. The sixth survey of the Troms $\varnothing$ study (Tromsø 6) in 2007-08: collaborative research in the interface between clinical medicine and epidemiology: study objectives, design, data collection procedures, and attendance in a multipurpose population-based health survey. Scand J Public Health 2013;41:65-80.

14 Jacobsen BK, Eggen AE, Mathiesen EB, et al. Cohort profile: the Tromso study. Int J Epidemiol 2012;41:961-7.

15 World Health Organization. Obesity: preventing and managing the global epidemic. Report of a who consultation. World Health Organ Tech Rep Ser 2000;894:1-253.

16 Sorkin JD, Muller DC, Andres R. Longitudinal change in the heights of men and women: consequential Eftects on body mass index. Epidemiol Rev 1999;21:247-60.

17 SAS Institute Inc. SAS/STAT User's Guide, Version 9. Cary,NC: SAS Institute, 2004.

18 R Core Team. R: a language and environment for statistical computing. Vienna, Austria: R Foundation for Statistical Computing, 2016.

19 Wickham H. ggplot2: elegant graphics for data analysis. New York: Springer Verlag, 2016.

20 Hales CM, Fryar CD, Carroll MD, et al. Trends in obesity and severe obesity prevalence in US youth and adults by sex and age, 2007 2008 to 2015-2016. JAMA 2018;319:1723-5.

21 Molarius A, Lindén-Boström M, Granström F, et al. Obesity continues to increase in the majority of the population in mid-Sweden-a 12year follow-up. Eur J Public Health 2016;26:622-7.

22 Verweij LM, Terwee CB, Proper KI, et al. Measurement error of waist circumference: gaps in knowledge. Public Health Nutr 2013;16:281-8.

23 Midthjell K, Lee CMY, Langhammer A, et al. Trends in overweight and obesity over 22 years in a large adult population: the HUNT Study, N orway. Clin Obes 2013;3:12-20.

24 Lund Haheim L, Håheim LL, Lund Larsen PG, Søgaard AJ. Risk factors associated with body mass index increase in men at 28 years follow-up. QJM 2006;99:665-71.

25 Drøyvold WB, Nilsen TIL, Krüger $\varnothing$, et al. Change in height, weight and body mass index: longitudinal data from the HUNT study in Norway. Int J Obes 2006;30:935-9.

26 Juhaeri J, Stevens J, Jones DW, et al. Associations of aging and birth cohort with body mass index in a biethnic cohort. Obes Res 2003;11:426-33.

27 Caman OK, Calling S, Midlöv P, et al. Longitudinal age-and cohort trends in body mass index in Sweden--a 24-year follow-up study. BMC Public Health 2013;13:893.

28 Reas DL, Nygård JF, Svensson E, et al. Changes in body mass index by age, gender, and socio-economic status among a cohort of Norwegian men and women (1990-2001). BMC Public Health 2007; 7:269

29 Nooyens ACJ, Visscher TLS, Verschuren WMM, et al. Age, period and cohort effects on body weight and body mass index in adults: the Doetinchem cohort study. Public Health Nutr 2009;12:862-70.

30 Tanamas SK, Shaw JE, Backholer K, et al. Twelve-year weight change, waist circumference change and incident obesity: the Australian diabetes, obesity and lifestyle study. Obesity 2014;22:1538-45.

31 Ebrahimi-Mameghani M, Scott JA, Der G, et al. Changes in weight and waist circumference over 9 years in a Scottish population. Eur J Clin Nutr 2008;62:1208-14.

32 Jacobsen BK, Melhus M, Kvaløy K, et al. A descriptive study of tenyear longitudinal changes in weight and waist circumference in the multi-ethnic rural Northern Norway. The SAMINOR study, 2003-2014 PLoS One 2020;15:e0229234.

33 Walls HL, Stevenson CE, Mannan HR, et al. Comparing trends in BMI and waist circumference. Obesity 2011;19:216-9.

34 Elobeid MA, Desmond RA, Thomas O, et al. Waist circumference values are increasing beyond those expected from BMI Increases** Obesity 2007;15:2380-3.

35 Freedman DS, Ford ES. Are the recent secular increases in the waist circumference of adults independent of changes in BMI? Am J Clin Nutr 2015;101:425-31.

36 Chimeddamba O, Gearon E, Brilleman SL, et al. Increases in waist circumference independent of weight in Mongolia over the last decade: the Mongolian steps surveys. BMC Obes 2017;4:19.

37 Gearon E, Tanamas SK, Stevenson C, et al. Changes in waist circumference independent of weight: implications for population level monitoring of obesity. Prev Med 2018;111:378-83.

38 Fildes A, Charlton J, Rudisill C, et al. Probability of an obese person attaining normal body weight: cohort study using electronic health records. Am J Public Health 2015;105:e54-9.

39 Vandevijvere S, Chow CC, Hall KD, et al. Increased food energy supply as a major driver of the obesity epidemic: a global analysis. Bull World Health Organ 2015;93:446-56. 
40 Lundblad MW, Andersen LF, Jacobsen BK, et al. Energy and nutrient intakes in relation to national nutrition recommendations in a Norwegian population-based sample: the Troms $\varnothing$ study 2015-16. Food Nutr Res 2019;63.

41 Morseth B, Hopstock LA. Time trends in physical activity in the Tromsø study: an update. PLoS One 2020;15:e0231581.
42 Norwegian Institute of Public Health. Overweight and obesity in adults (indicator 14). Available: https://www.fhi.no/en/op/Indicatorsfor-NCD/Overweight-and-obesity/overvekt-og-fedme-blant-voksneindikator-14/ [Accessed 11 Mar 2020].

43 Connor Gorber S, Tremblay M, Moher D, et al. A comparison of direct vs. self-report measures for assessing height, weight and body mass index: a systematic review. Obes Rev 2007;8:307-26. 